\title{
Chwile, miejsca, ludzie, przedmioty
}

\author{
Adam Nobis \\ https://orcid.org/0000-0001-8093-1283
}

Giełda Staroci na Rynku Świdnicy jest terenem badań związków zachodzących między przedmiotami, miejscami i czasami. Zgromadzone tu przedmioty związkami przyczynowymi, czasowymi, przestrzennymi, materialnymi, znaczeniowymi, wartościowymi uwikłane są w zależności z innymi miejscami i czasami. Swoją obecnością na Rynku współtworzą jego przestrzeń relacji. Jednocześnie wikłają tę przestrzeń we własne powiązania $z$ wieloma innymi miejscami i chwilami bliższymi i odległymi. Wszystko to sprawia, że w szczególny sposób Rynek jest światem, a świat Rynkiem. Teraźniejszość jest przeszłością, a przeszłość teraźniejszością. Wnioski te dotyczą nie tylko świdnickiego Rynku, lecz także innych miejsc i chwil, podważając nasze dotychczasowe postrzeganie tych relacji.

Słowa kluczowe: czas, miejsce, przedmioty, lokalność, globalność

\section{Mały klaser ze znaczkami}

Jesteśmy w Świdnicy. To miasto na Śląsku, w Polsce, Europie, prawie 60 tys. mieszkańców, w jego centrum średniowieczny Rynek. Jest pierwsza niedziela miesiąca, 5 maja 2019 r., więc dziś odbywa się tu Giełda Staroci, Numizmatów i Osobliwości jak co miesiąc od 1977 r. Rynek ma kształt kwadratu o boku ok. 100 m. Giełda nie mieści się w jego granicach. Stoiska, przedmioty,

ADAM NOBIS, dr hab., prof. Uniwersytetu Wrocławskiego, Uniwersytet Wrocławski; adres do korespondencji: Instytut Kulturoznawstwa, Pracownia Studiów Globalnych, 50-139 Wrocław, ul. Szewska 50; email: adam.nobis@uwr.edu.pl 
ludzie zapełniają także okoliczne uliczki, skwery. Na ul. Różanej na chodniku przy budynku Sądu Okręgowego wśród wypełnionych kartonów jest jeden z klaserami, z których wysypują się pocztowe znaczki. Wśród nich mały klaser o wymiarach 18,5 x $13,5 \mathrm{~cm}$ :

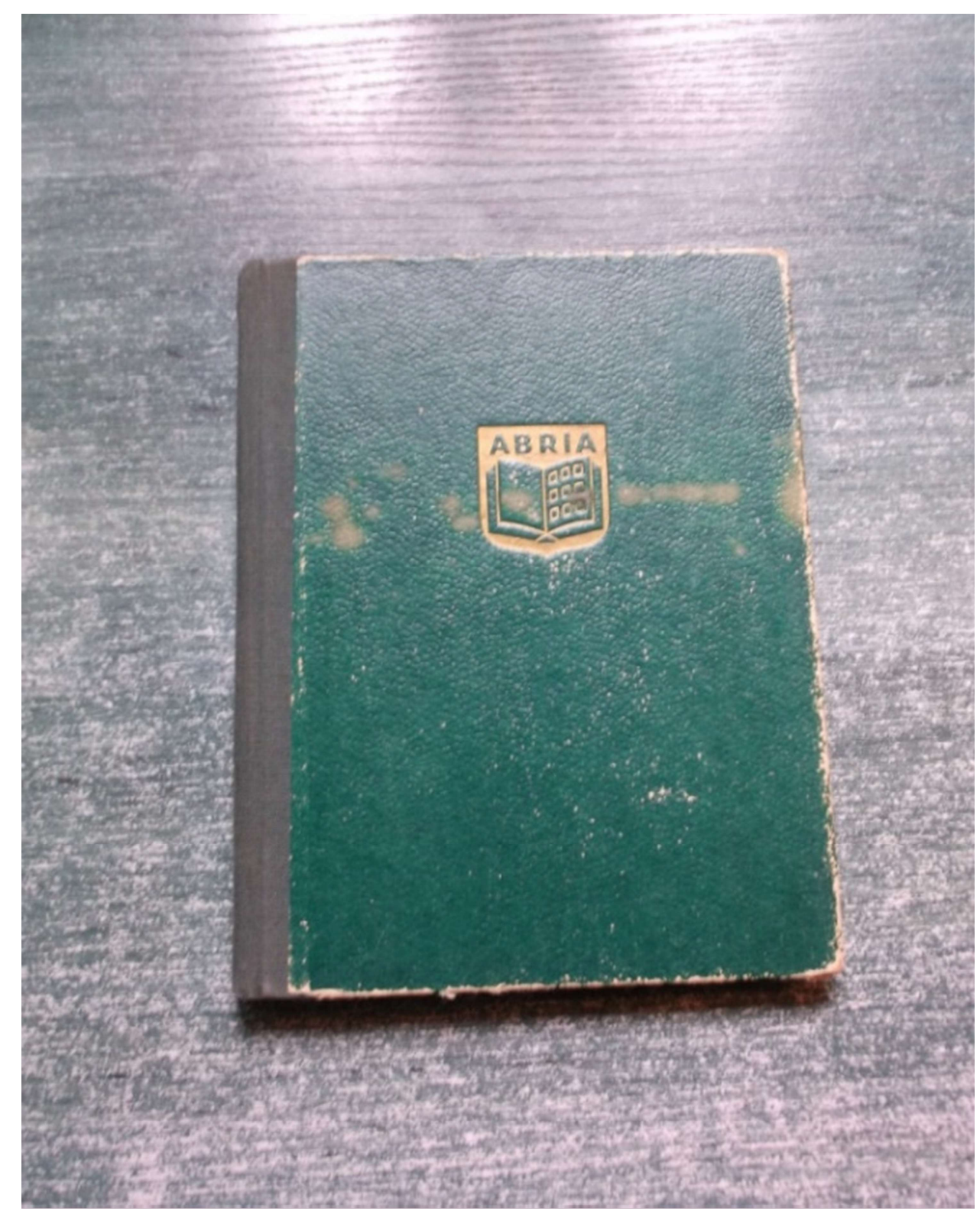

Fot. 1. Klaser

Widoczny napis ABRIA to skrót od nazwy producenta Ascherslebener Briefmarken-Albenverlag, firmy $\mathrm{z}$ NRD z siedzibą na Johannisplatz 2 
w Aschersleben w Saksonii-Anhalt w środkowych Niemczech. Na okładce jest stempel „Art. Nr. 449/33” ale to ręczny wpis czyni z klasera przedmiot unikalny:

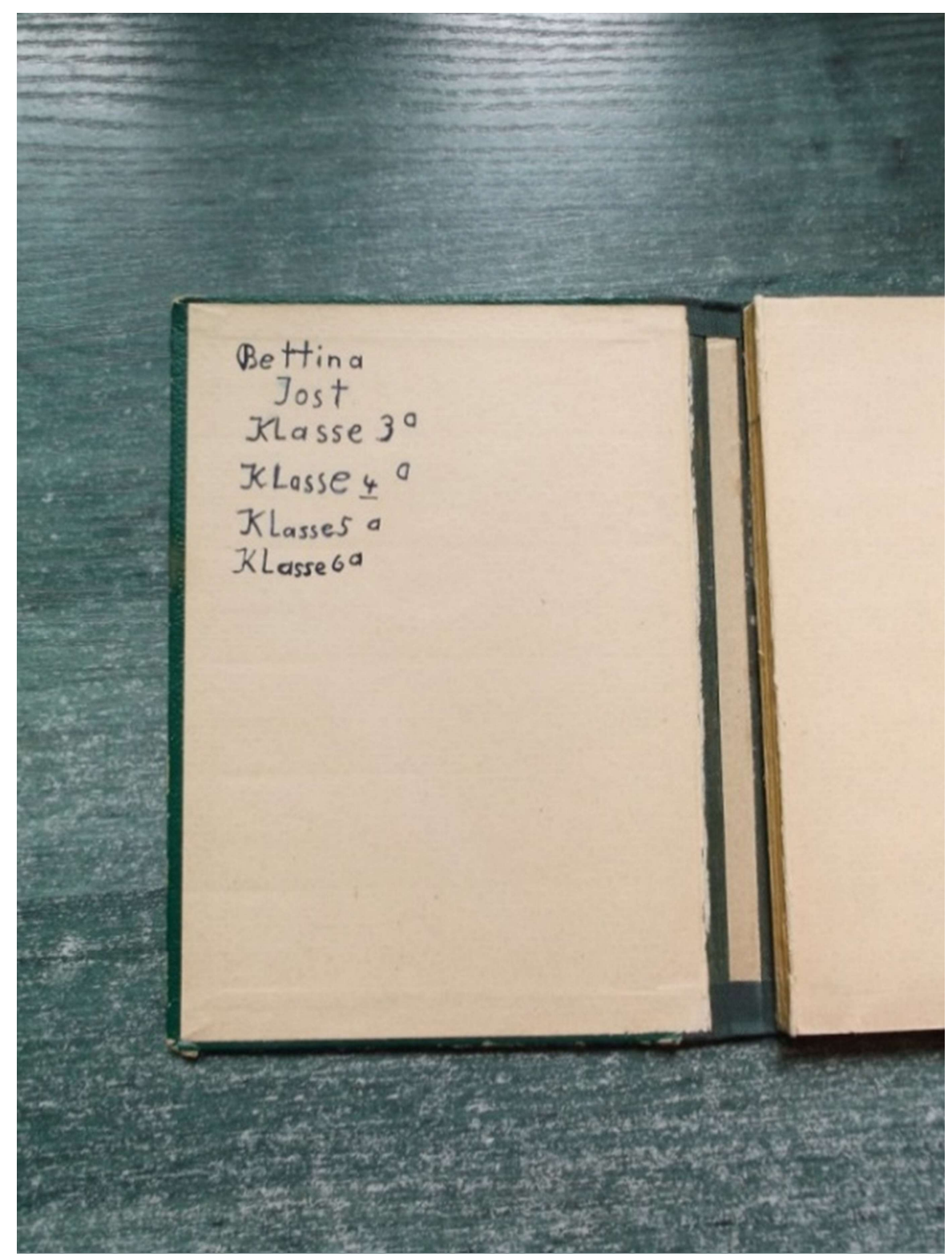

Fot. 2. Wpis w klaserze

Mamy imię i nazwisko dziewczynki, Bettina Jost, a kolejne klasy: 3a, 4a, 5a i 6a to zapis splotu historii jej i klasera. W nim na 12 stroniczkach są znaczki 
z różnych krajów świata. Belgia sąsiaduje z Indiami, Argentyna leży obok Szwajcarii, gdzie indziej Włochy, Chile oraz Szwecja, Turcja i Kanada. Ta specyficzna topografia czyni z albumu niepowtarzalny przedmiot i miejsce swoiste. Staje się on też szczególnym odwzorowaniem świata.

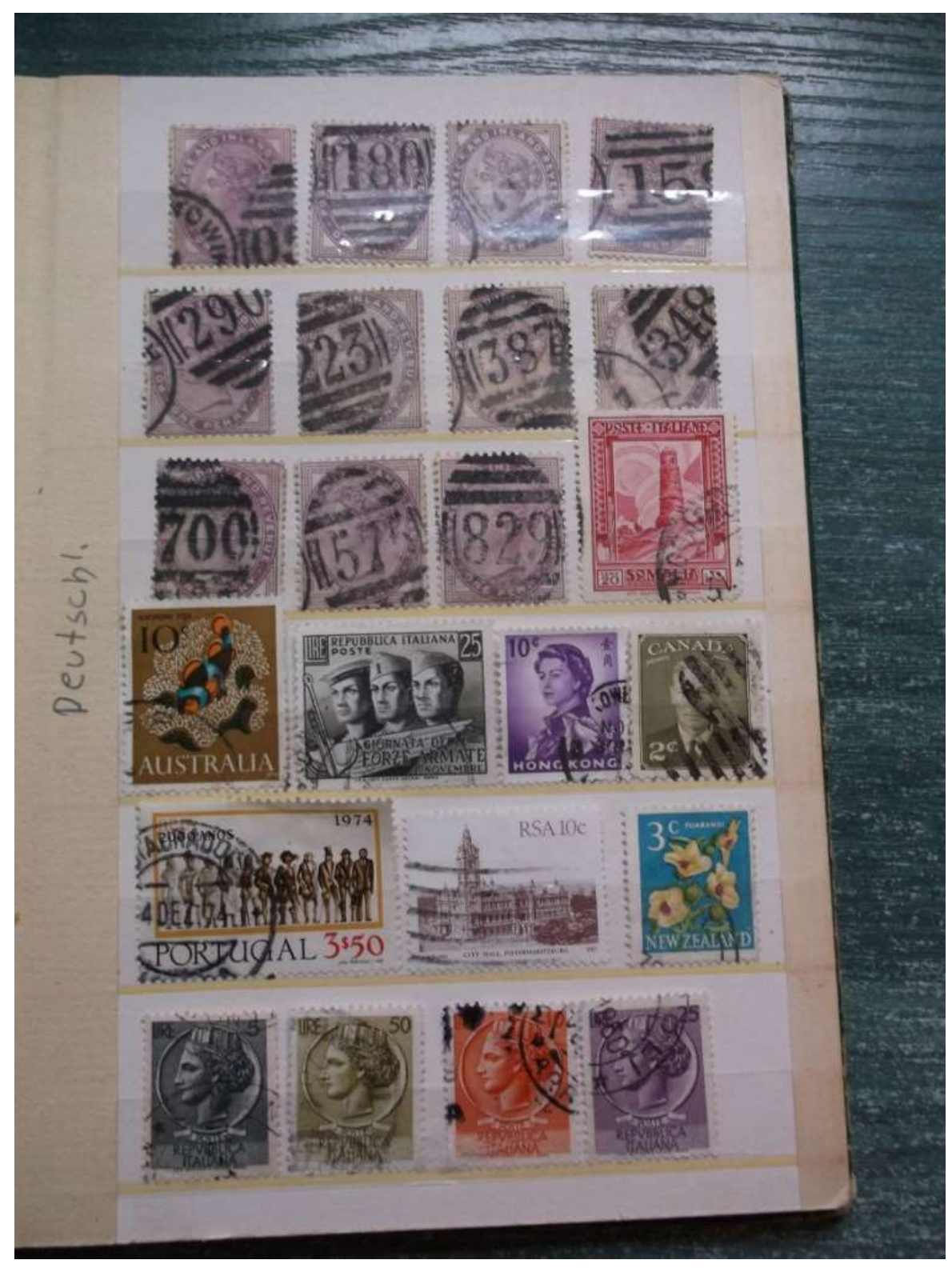

Fot. 3. Jedna ze stron 
Na jednej ze stron widoczny jest ręczny wpis „Deutschl.” a na niej nie niemieckie lecz brytyjskie znaczki z królową Wiktorią, włoskie z personifikacją Italii, a także z Australii, Nowej Zelandii, Kanady, Portugalii, RPA. Obok siebie znajdują się znaczki z różnych krajów świata i różnych czasów: wiktoriańskie z 2. połowy XIX stulecia towarzyszą włoskim z 2. połowy XX wieku, a Elżbieta II z Hong Kongu z lat 1962-67 towarzyszy swojemu ojcu Jerzemu VI z Kanady z 1949 r.

Czy nasz klaser nie jest jak markownik, którym zachwyca się Józef N. z opowiadania Wiosna Brunona Schulza: „to była prawdziwa księga blasku! Otworzyłem ją i zajaśniało przede mną kolorami światów, wiatrem nie objętych przestrzeni, panorama wirujących horyzontów. [...] Kanada, Honduras, Nikaragua, Abrakadabra, Hiporabundia” ${ }^{1}$, a o znaczkach pisze: „Były to przedziwne skróty i formuły, recepty na cywilizacje, poręczne amulety, w których można było ująć między dwa palce esencję klimatów i prowincyj. Były to przekazy na imperia i republiki, na archipelagi i kontynenty"2. W naszym klaserze oprócz dwóch królowych i króla Wielkiej Brytanii, personifikacji Italii, mamy ukrywającą się w koralowcu rybę amfitriona z Australii, XV-wieczną wieżę Mnara z Mogadiszu na znaczku z włoskiej kolonii Somali z lat 1932-7, kwiat parangi, który jest herbem Nowej Zelandii na znaczku z tego kraju z lat 1960-7, żołnierzy włoskich, ratusz z Pietermaritzburga w RPA i mężczyzn w strojach od rzymskich po współczesne z Portugalii z 1974 r. Józef uznał, że „Markownik jest księgą uniwersalną, jest kompendium wszelkiej wiedzy o ludzkim”3, nie tylko o różnych „prowincyjach”, lecz także i czasach. Chciałbym inaczej potraktować nasz klaser. Nie jako Księgę wiedzy o świecie lecz jako drobny jego fragment, na który składa się - pomimo jego niewielkich rozmiarów - wiele zjawisk, miejsc, wydarzeń świata $\mathrm{z}$ różnych czasów.

\section{Stemple}

Są tu znaczki stemplowane, choć często stemple są niewyraźne. Zatrzymajmy się przy 7 znaczkach, na których odczytać można miejsce i czas ostem-

\footnotetext{
${ }^{1}$ Bruno Schultz, Sklepy cynamonowe (Kraków: Wydawnictwo Literackie, 1978), 151.

${ }^{2}$ Tamże, 148.

${ }^{3}$ Tamże, 171.
} 
plowania. W jakiej kolejności? Od najstarszego do najnowszego, a może od najmniejszego do największego? Od tego, który przebył najdłuższą drogę? Niech będzie kolejność z fotografii. To małe skrawki papieru. Największy w środku ma rozmiar $2,5 \times 4 \mathrm{~cm}$. Ten poniżej to $2 \times 2,5 \mathrm{~cm}$.

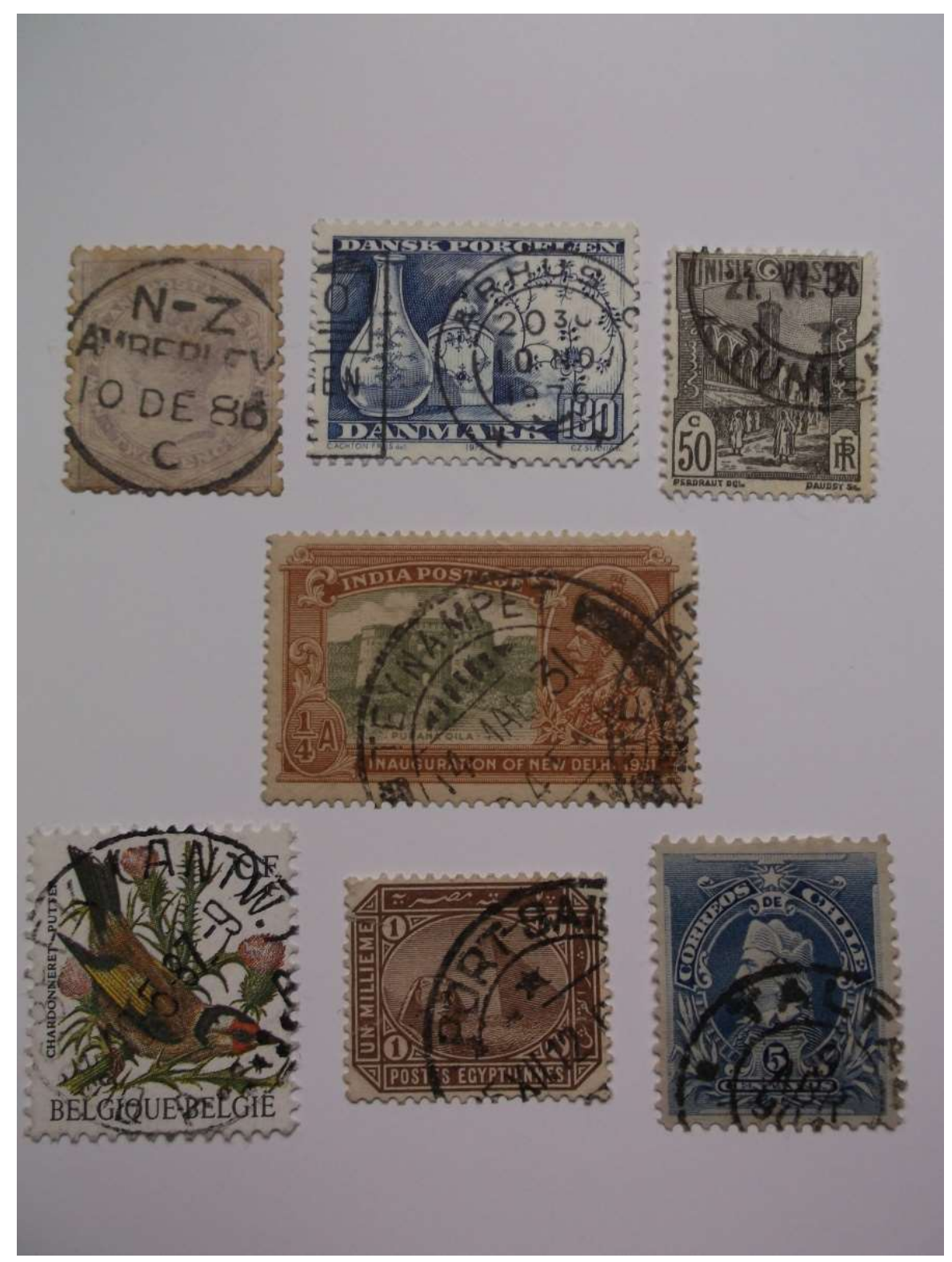

Fot. 4. Znaczki

Na pierwszym znaczku w górnym rzędzie widać stempel pocztowy, a na nim nie całkiem wyraźnie „N-Z AMBERLEY 10 DE 86 C”. Dzięki książkom, 
komputerom $\mathrm{z}$ innych miejsc dowiemy się, że Amberley to miejscowość, dziś ok. 2 tys. mieszkańców i jak kiedyś położona na wschodnim wybrzeżu Wyspy Południowej Nowej Zelandii w Zatoce Pegaza nad Pacyfikiem. Po nazwie miejscowości jest data - 10 December 1886, czyli 10 grudnia 1886 r. Tu oczywiście korzystamy ze słowników lub znajomości języka obcego, nabytej także poza świdnickim Rynkiem i jakiś czas temu. Na stemplu mamy miejsce i czas ostemplowania. Na wyblakłym jasnoliliowym znaczku umieszczona jest kobieca głowa, nazwa kraju „NEW ZEALAND” i nominał „TWO PENCE”, czyli dwa pensy. Jeśli widzieliśmy już w życiu trochę znaczków z różnych lat, to możemy wiedzieć, że 86 to rok 1886, a nie 1986 czy inny. Zwróćmy uwagę, że do odczytania i zrozumienia umieszczonych na tym papierku znaczeń potrzebna jest nam wiedza zdobyta w innych miejscach i czasach dzięki innym przedmiotom. Dzięki innym spotkanym już gdzie indziej i kiedy indziej znaczkom możemy wiedzieć, że ten przedstawia Wiktorię, królową Wielkiej Brytanii, do której należała wówczas Nowa Zelandia. Czy trzeba dodać, że wcześniej, gdzie indziej i przy pomocy innych przedmiotów nauczyliśmy się czytać litery nazywane łacińskimi? Na środkowym znaczku w górnym rzędzie na stemplu widzimy: „ÅRHUS $20^{30} 10$ NO 1976”, gdzie Århus to miasto w Danii, około 240 tys. mieszkańców, ulokowane na wschodnim, bałtyckim wybrzeżu Jutlandii, o czym dowiedzieć się możemy w domu korzystając z encyklopedii w twardej okładce lub z wirtualnej Wikipedii, albo na Rynku, jeśli mamy telefon $\mathrm{z}$ dostępem do sieci. "10 NO" to "10 November", czyli 10 listopada 1976 r. (znowu nabyta znajomość języka obcego) a $20^{30}$ to czas ostemplowania. Na samym znaczku mamy "DANSK PORCELEN", “DANMARK” i 130, czyli duńska porcelana, Dania i 130 øre (tu potrzebna jest nie znajomość języka lecz waluty kraju). Na samym dole znaczka malutkimi literkami z lewej "C.ACHTON FRIIS” a z prawej „CZ.SLANIA”. Z filatelistycznych katalogów dowiemy się, że to twórcy znaczka, rytownik i projektant, czyli Claus Achton Friis i Czesław Słania. Na samym znaczku dwa porcelanowe naczynia. Na stemplu trzeciego po prawej widzimy 
„21. VI. 34 TUNIS”, czyli 21 czerwca 1934 r. i Tunis. Dzięki innym przedmiotom, miejscom i chwilom możemy wiedzieć, że to stolica Tunezji, prawie półmilionowe miasto nad Morzem Śródziemnym. Na samym znaczku „TUNESIE POSTES 50c i RF”, czyli Poczta Tunezyjska, 50 centymów i Republika Francuska, bo do niej wtedy należał ten kraj (czy znaczek o tym informuje?). $\mathrm{Na}$ znaczku ulica z ludźmi i majestatyczna budowla $\mathrm{z}$ wieżą a po obu stronach tekst arabski: البوسطة التونسية. Dzięki pomocy osoby znającej ten język dowiaduję się, że to „()«al-busta at-tunisijja» (w transkrypcji polskiej), czyli «poczta tunezyjska»”. ${ }^{4}$ Na czwartym znaczku mamy „INDIA POSTAGE”, „1/4 A” i „INAUGURATION OF NEW DELHI" oraz popiersie mężczyzny a na stemplu słabo widoczne „TEYNAMPET 14 MAR 31”, czyli 14 marca 1931 r. Gdzie indziej i kiedy indziej możemy dowiedzieć się, że Teynampet to nazwa dzielnicy Chennai, dawnego Madras, dziś prawie pięciomilionowego miasta, które ulokowane jest na wschodnim wybrzeżu Południowych Indii nad Oceanem Indyjskim i - jak wówczas - nadal jest centrum biznesu obsługującego związki Indii ze światem. Na znaczku stara budowla i podpis „PURANA QILA”. Znając znaczki możemy wiedzieć, że „1/4 A” to nominał określający wartość znaczka. Możemy nawet gdzieś i kiedyś spotkać informację, że „A” to indyjski pieniądz anna. Na piątym znaczku trudno nie zauważyć kolorowego ptaka i tekst „BELGIQUE - BELGIE”, „CHARDONNERET - PUTTER” i „9 F”. Znowu potrzebujemy wiedzy zdobytej w innych miejscach i chwilach niż nasze spotkanie na świdnickim Rynku. Przydatna jest też wiedza, że w Belgii używane są dwa języki: francuski i niderlandzki. Wtedy wiemy, że w obu językach mamy i nazwę kraju i ptaka, który po polsku nazywany jest szczygłem. Na stemplu widzimy „BORSBEEK (ANTW.) 19-5-87”. Z Wikipedii dowiemy się, że Borsbeek to mała dzielnica półmilionowej Antwerpii. Czy domyślimy się, że 87 to 1987, a nie 1887? Szósty znaczek to rozpoznawana przez wielu piramida, a przed nią Sfinks, tekst „1”, „UN MILLEME” i „POSTES EGYPTIENNES”, a na stemplu fragment tekstu „PORT-SAI” i „5 XII. 12” oraz tekst arabski. Kolejny raz dzięki informacjom

${ }^{4}$ Olga Kotynia, e-mail z dnia 06.09.2019. 
spoza naszego tu i teraz świdnickiego Rynku możemy wiedzieć, że niepełny jak widać na fotografii - tekst „Port-Sai” to Port Said, ponad półmilionowe dziś miasto nad Morzem Śródziemnym przy Kanale Sueskim a „12” w dacie to skrót od 1912. Na ostatnim znaczku widzimy popiersie mężczyzny, tekst „CORREOS DE CHILE 5 CENTAVOS i jak poprzednio niekompletny stempel „TALTA” i „4 ABR 901”. Ponownie dzięki innym informacjom możemy wiedzieć, że niepełny napis „Talta” to Taltal, nazwa miejscowości (dziś ok. 10 tys. mieszkańców) na północnym wybrzeżu Chile nad Pacyfikiem, „ABR” to abril, po hiszpańsku kwiecień a 901 to $1901 \mathrm{r}$.

\section{Różne miejsca w jednym miejscu}

$\mathrm{Na}$ chodniku, w kartonie, w małym klaserze znajdują się obok siebie znaczki, które z klaserem i kartonem są częścią Giełdy Staroci na świdnickim Rynku, ale kiedyś - o czym świadczą stemple - były częścią innych miejsc. Jeden został ostemplowany w pocztowym urzędzie w Amberley, gdzie nadal stoi dobrze zachowany, parterowy, drewniany budynek Old Post Office z małymi pomieszczeniami. Był drobną częścią tej lokalności na Wyspie Południowej, na wybrzeżu ogromnego Oceanu Spokojnego. Kolejny znaczek pochodzi z przeciwnej strony globu, z wybrzeża Bałtyku, który jest częścią Atlantyku, z Århus. Nim znalazł się tu i teraz, został ostemplowany w tamtejszym pocztowym urzędzie, gdzie wraz z datownikiem, blatem, segregatorami na listy był częścią tamtej lokalności. Następny przybył z afrykańskiego wybrzeża Morza Śródziemnego, z Tunisu, gdzie także był częścią konkretnego miejsca, choć zapewne meblami, ludźmi, urządzeniami, różniło się ono od miejsc z Århus i Amberley. W Tunisie i w Århus mogło być kilka pocztowych urzędów, a brak widocznych oznaczeń na stemplu nie pozwala nam ustalić adresu miejsca ostemplowania. Niemniej jednak i tak ostemplowane zostały w jakimś miejscu ręką osoby używającej konkretnego datownika, choć dokładny adres miejsca, dane personalne 
urzędnika, charakterystyka urządzenia pozostają nam nieznane. Czwarty pochodzi z wybrzeża Oceanu Indyjskiego, z Chennai, dawnego Madrasu, z kolonialnej wówczas dzielnicy Teynampet, gdzie poczta mieściła się na Anna Salai Road wtedy i dziś po południowej stronie Katedry Św. Jerzego. Miejsca pochodzenia kolejnego znaczka szukać musimy w belgijskiej Antwerpii, w dzielnicy Borsbeek, gdzie pod adresem Robianostraat $56 \mathrm{w}$ małym piętrowym budynku nadal czynna jest poczta. Następny ostęplowano nad Morzem Śródziemnym w egipskim Port Said, w urzędzie, który mieścił się w dużym, dwukondygnacyjnym, eleganckim budynku przy Fouad Boulevard, a zobaczyć go możemy na starej fotografii przy pomocy domowego komputera lub telefonu'. Ostatni stempel pochodzi z chilijskiego wybrzeża Pacyfiku, z Taltal, z pocztowego urzędu w tej miejscowości.

Zatem obok siebie w klaserze i kartonie leżą znaczki z miejsc nie tylko odległych od świdnickiego Rynku, lecz także odległych od siebie, z różnych kontynentów, z nad różnych oceanów. Kiedyś nie tylko były częścią nieznanych nam konkretnych lokalności, lecz nawet je współtworzyły. Wraz z innymi znaczkami, listami, pocztowymi datownikami, meblami, urzednikami i nadawcami listów tworzyły specyficzne układy relacji, które konstytuowały przestrzenie tych lokalności mieszczących się w pomieszczeniach obszernych lub ciasnych, eleganckich lub brzydkich, czystych lub brudnych, dających schronienie od upału lub zimna, co także nadawało tym miejscom specyficzny charakter. Znaczki były częścią tych miejsc. Dzisiejszej niedzieli na czas Giełdy Staroci są częścią innego miejsca. Wraz z innymi z różnych stron świata leżą w małym klaserze nadając mu unikalny charakter. Przedmiot ten wypełniony znaczkami z jednego tylko kraju lub zapałczanymi etykietami albo po prostu pusty, miałby inne znaczenie i wartość. Klaser ten $\mathrm{z}$ innymi wypełniając duży karton określa z kolei jego znaczenie i wartość, a karton z ogromem innych wystawionych na sprzedaż przedmiotów, sprzedającymi, ogladającymi, wędrującymi między sto-

${ }^{5}$ „Port Said Post Office”, https://www.ansichtskartenversand.com/ak/93-old-postcard/34029City-Port-Said/8218542-AK-Port-Said-Egyptian-Post-Office/? \&lang=2 (dostęp 21.08.2019). 
iskami, kupującymi tworzy złożoną przestrzeń relacji konstytuujących dzisiejszą Giełdę na świdnickim Rynku. On sam nie jest ani biernym obserwatorem, ani jedynie miejscem, w którym to się dzieje. Jest aktywnym i istotnym uczestnikiem wraz z kamiennym brukiem, fontannami, rzeźbami, ławkami, murkami, podcieniami, okolicznymi budynkami, uliczkami, skwerami, drzewami, umożliwia spotkania ludzi z przedmiotami, ludzi z ludźmi, przedmiotów z przedmiotami. Jest aktywnym uczestnikiem tych spotkań, chroni przed upałem, deszczem, wiatrem ludzi i przedmioty. Jak bez znaczków, listów, datowników i urzędników nie byłoby poczt, tak bez Rynku, ogromu ludzi i przedmiotów nie byłoby dzisiejszej Giełdy. Nasze znaczki współuczestniczą w konstytuowaniu dzisiejszego wydarzenia. A Rynek i jego przestrzeń nie tylko także w tym współuczestniczą lecz są również kształtowane. Dzisiejsze spotkanie ludzi, przedmiotów i świdnickiego Rynku tworzy przestrzeń relacji o trudnej do wyobrażenia i zrozumienia złożoności, a znaczki są częścia tej przestrzeni. Są tu i teraz obok siebie, obok przechodzących i oglądających ludzi, obok innych przedmiotów. Jednocześnie pozostają w specyficznych relacjach, związkach z miejscami ich ostemplowania. Gdyby nie znajdowały się w wymienionych miejscach i nie zostały tam ostemplowane, nie posiadałyby widocznych na świdnickim Rynku odciśniętych stempli z informacją o miejscu i czasie ich ostemplowania i byłyby pozbawione znaczeń i wartości, które stały się częścią ich historii i ich samych, a teraz stały się częścią przestrzeni Rynku.

\section{Różne czasy w jednym czasie}

Wróćmy do czasu, czy czasów ostemplowania. Znaczek z Amberley ma na stemplu datę 10 grudnia 1886 r. Oznacza to nie tylko, że wtedy go ostemplowano, lecz także że wtedy był w tej miejscowości, a dokładniej w jej pocztowym urzędzie. Ten z Århus ma datę 10 listopada 1976 r. i godzinę $20^{30}$, co nie musi oznaczać dokładnie co do minuty czasu ostemplowania, jeśli ustawienie czasowe stempla było zmieniane co pół godziny. Ale i tak możemy przyjąć, że czas ostemplowania to krótka chwila, nawet jeśli nie wiemy dokładnie która. Ten z Tunisu to 21 czerwca 1934 r., z Teynampet to 14 marca 1931 r., Borsebeek to 19 maja 1987 r., Port Said to 5 grudnia 1912 r. a Taltal to 4 kwietnia 1901 r. Co 
to znaczy? Czas ostemplowania najstarszego od naszej Giełdy dzieli około 133 lata, a najmłodszego 32. Oba dzieli od siebie około 101 lat. To 1212 miesięcy a ile chwil? Mimo, że ostemplowano je w różnych czasach, to wspólnie uczestniczą w dzisiejszym spotkaniu ludzi, przedmiotów, Rynku, spacerujących psów, ptaków siadających na drzewa. Uczestniczą w dzisiejszej teraźniejszości z innymi uczestnikami. Jednak nadal zachowały swoje relacje z czasem ich ostemplowania, podobnie jak z jego miejscem. Czy trzeba powtórzyć? Gdyby nie były częścią miejsc i czasu swojego ostemplowania nie posiadałyby swoich stempli. Te wydarzenia są nadal częścią historii tych znaczków i ich samych, a one same są nadal drobnymi fragmentami tych odległych w czasie i przestrzeni miejsc, co nie przeszkadza im być częścią naszego wydarzenia tu i teraz. Zresztą czy nie dlatego tu są, że są okruchami innych rzeczywistości? Innych czasów i miejsc? Nie zerwały swoich związków ze swoją przeszłością. Nadal są jej fragmentami, a ona $z$ kolei jest dosłownie odciśnięta na nich pocztowym stemplem, stając się ich częścią.

\section{Spotkanie różnych miejsc i czasów na jednym rynku: ludzie, bóstwa, zwierzęta, rośliny, przedmioty, idee...}

Jak to możliwe, by znaczki były częścią świdnickiego Rynku w czasie naszej Giełdy, a jednocześnie fragmentami innych odległych miejsc? Julia Graham i Katherine Gibson we wspólnie napisanym tekście podpisanym pseudonimem „J.K.Gibson-Graham” wyjaśniają, by nie postrzegać lokalności i globalności jako przeciwieństw. Postulują nieantagonistyczne pojmowanie zachodzącej między nimi bliskiej więzi, gdy globalność jest lokalnością a lokalność globalnością. Z jednej strony „to, co globalne jest lokalne w tym znaczeniu, że odnosi się do procesów, które dotyczą jedynie określonych (lokalnych) części globu”, z drugiej strony - „to, co lokalne jest globalne [...], zawiera relacje, które wykraczają poza; to co globalne jest częścią tego, co konstytuuje lokalność”6. To, co jest globalne, nie istnieje poza lokalnościami lecz w nich, choć nie zawsze we wszystkich. To, co lokalne uwikłane jest w rozmaite związki z innymi lokalnościami, mniej lub bardziej odległymi i rozległą siecią relacji między nimi. Nasze

${ }^{6}$ J. K. Gibson-Graham, „Beyond Global vs. Local: Economic Politics Outside the Binary Frame", w: Geographies of Power: Placing Scale, red. Andrew Herod, Melissa Wright (Oxford: Blackwell, 2002), 30. 
znaczki wraz z wieloma innymi przedmiotami na świdnickim Rynku w specyficzny sposób wychodzą naprzeciw postulatom autorek. Przybyły tu z różnych miejsc. Mniej lub bardziej odległych. Kiedyś były ich integralną częścią, a teraz są elementem świdnickiego spotkania, nie tracąc związków z miejscami pochodzenia i poprzedniego pobytu. I nadal są fragmentami tych miejsc. Stanowią więź między lokalnością Rynku i wieloma innymi lokalnościami różnych regionów świata. Znaczki nie są tu wyjątkiem. Czynią to z ogromem innych przedmiotów obecnych tu w tą niedzielę. Na przykład na innym stoisku wśród ceramicznych figurek, z których dzięki sygnaturom można odczytać miejsca produkcji i pochodzenia stoją i rozglądają się trzy orientalne postacie. Nie odnalazłem przy nich żadnych oznaczeń produkcji, lecz przypuszczam, że są przybyszami z dalekiego wschodu świdnickiego Rynku.

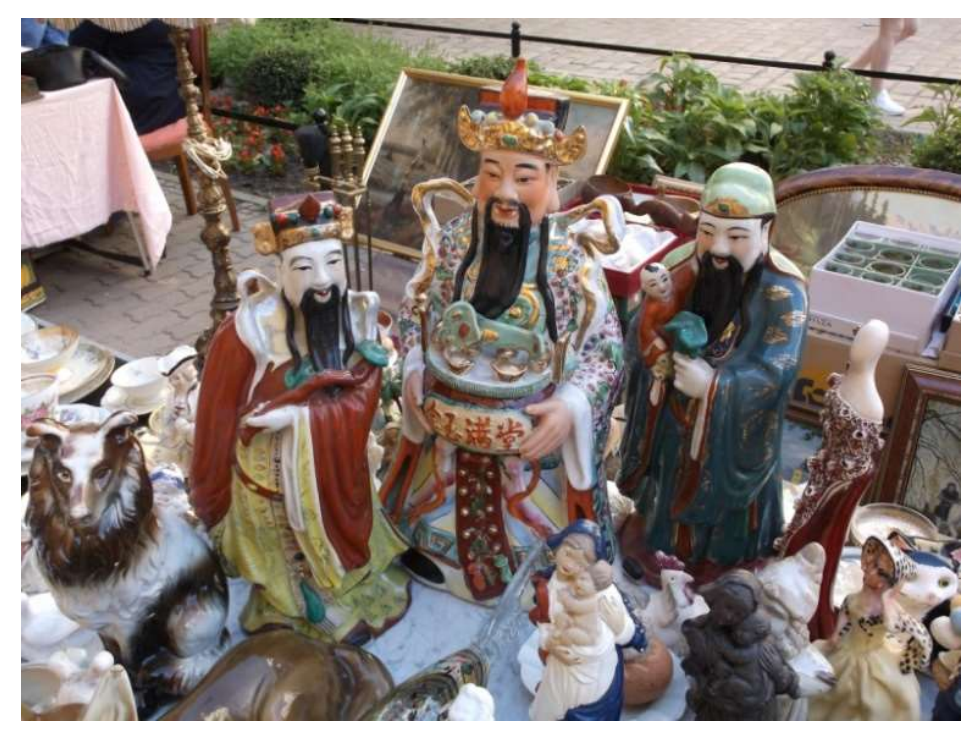

Fot. 5. Przybysze ze Wschodu

Albo Budda, o którym pani mówi, że został dla niej przywieziony z Tajlandii. Tu na Rynku odpoczywa w towarzystwie Madonn, których wizerunki na odwrotach posiadają informacje o miejscach i krajach pochodzenia: „Made in France”, „Made in Greece”, „Lwów”. 


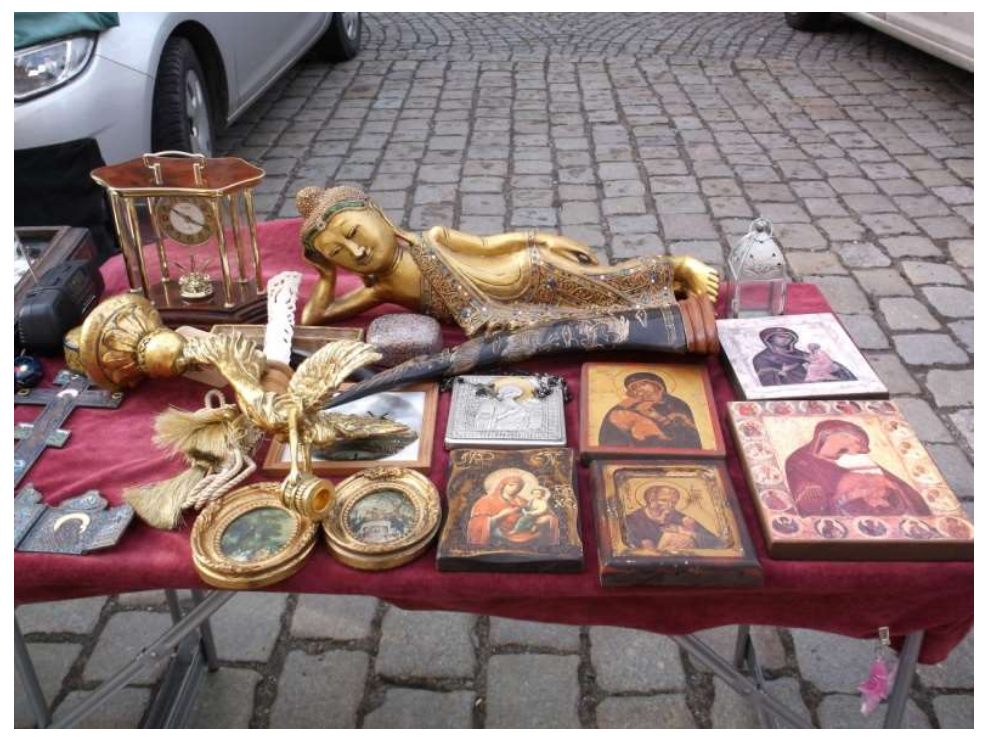

Fot. 6. Budda z Madonnami

Przedmioty te nie straciły związków z miejscami swego powstania, bo gdyby nie te miejsca, nie byłoby częścią świdnickiego Rynku. Na Madonnach widać farby $z$ tamtych miejsc, a czasem i specyficzny sposób ich nakładania. Znaczki mają na sobie tusz pobrany stemplem z leżącej obok niego poduszki i nadal odciśnięty jego specyficzny kształt. Ogrom przedmiotów i ich powiązań $z$ innymi miejscami wiąże Rynek z ogromem innych miejsc na Ziemi na wszystkim zamieszkałych przez człowieka kontynentach, czyniąc w swoisty sposób Rynek światem, a świat Rynkiem.

\section{Splot relacji}

A co z czasami, z których pochodzą znaczki i inne przedmioty obecne tu i teraz? Czy nie mamy do czynienia z pomieszaniem czasów? Bjørnar Olsen wyjaśnia: „to, co uważamy za nasz współczesny świat, nie jest utworzone z istnień pochodzących z tego samego okresu - teraźniejszości, lecz ma kształt 'spłaszczonego' wieloczasowego pola złożonej i rozproszonej stratygrafii nagromadzo- 
nych przeszłości. Teraźniejszość «składa się w zasadzie z palimpsestu wszystkich trwań przeszłości, które zostały zapisane w materii»"” . Zatem znaczki i inne przedmioty są nie tylko składnikami tego miejsca, będąc jednocześnie elementami innych miejsc, ale podobnie są częścią naszej teraźniejszości, będąc jednocześnie fragmentami innych czasów i chwil. Tym samym, zapełniając i konstytuując przestrzeń Rynku Giełdy Staroci, obecne w niej przedmioty swoimi powiązaniami wikłają tę przestrzeń w gąszcz zależności z ogromną ilością innych czasów i miejsc. Przy czym jeden przedmiot czy znaczek może być częścią złożonych splotów relacji, z którymi wiąże Rynek swoją obecnością. To zależności rozmaite: materialne, czasowe, przestrzenne, przyczynowo-skutkowe, znaczeniowe, wartości. Nie wszystkie rozpoznajemy, ale to nie znaczy, że nie istnieją. Gdy je rozpoznajemy, to zwykle dzięki przedmiotom, znaczeniom i wartościom spotkanym w innych miejscach i czasie.

Przykładem materialnego związku jest popielniczka, na której widzimy kobietę i inskrypcję: „made in Hawaii with lava by Coco Joe”. Jeśli wykonana jest z zastygłej hawajskiej lawy wulkanicznej, to oznacza, że nadal jest fragmentem tych odległych od świdnickiego Rynku wysp. Niestety nie znajdujemy informacji o czasie powstania tej rzeźby. W podobne materialne związki uwikłane są także i nasze znaczki, które także w innych czasach były częścią innych miejsc. W chwili ostemplowania były częścią pocztowych urzędów. W czasie produkcji były częścią drukarni. Wcześniej ich materia była częścią papierni a jeszcze wcześniej ich atomy węgla były częścią roślin. Czy możemy dodać, że wcześniej rośliny pobrały te atomy $\mathrm{z}$ atmosfery w postaci dwutlenku węgla $\mathrm{CO}_{2}$, który w trakcie fotosyntezy został rozłożony na węgiel wykorzystany do budowy ich ciał i tlen uwolniony do atmosfery? Może jeszcze moglibyśmy dopowiedzieć, że do fotosyntezy konieczna jest energia fotonu słonecznego światła? To oznacza związek naszych znaczków z kolejnymi miejscami: globalną atmosferą oraz Słońcem, naszą najbliższą gwiazdą, której światło potrzebuje nieco ponad $8 \mathrm{mi}$ nut, by pokonać odległość z jego powierzchni na Ziemię.

${ }^{7}$ Bjørnar Olsen, W obronie rzeczy. Archeologia i ontologia przedmiotów, tłum. Bożena Shallcross (Warszawa: Instytut Badań Literackich PAN, 2013), 247. 


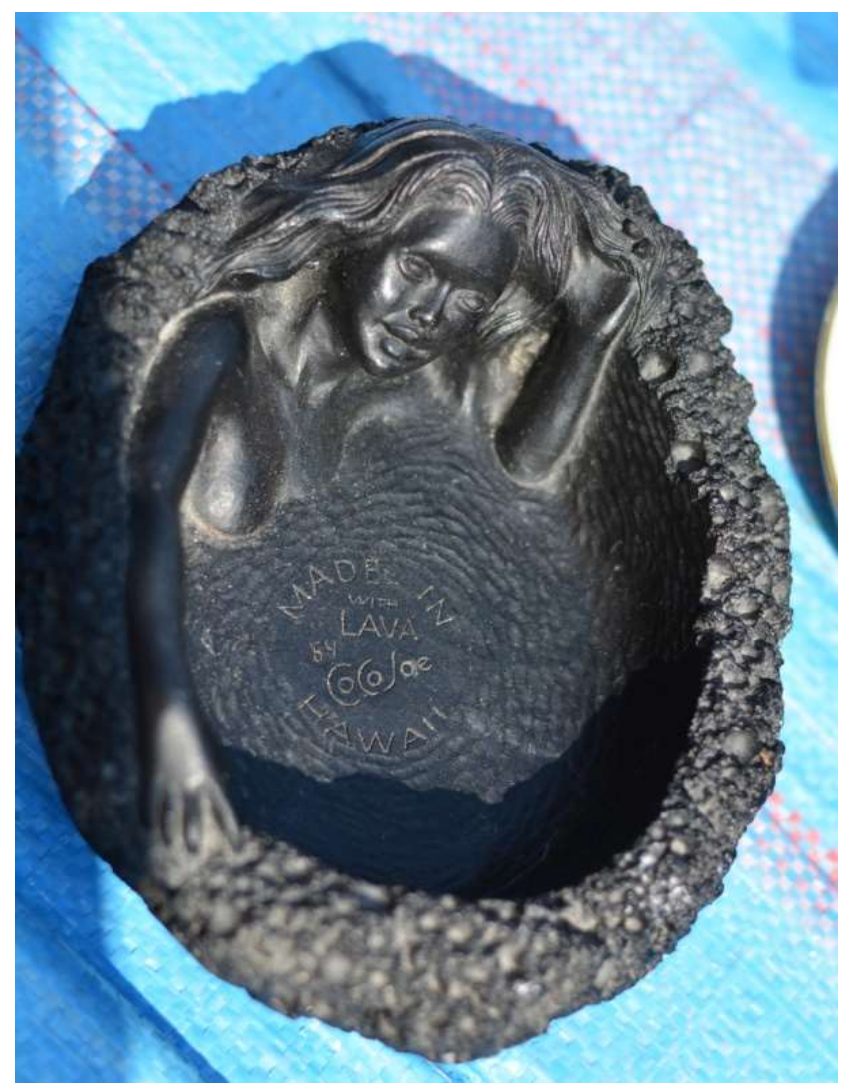

Fot. 7. Popielniczka

Dzięki katalogowi ${ }^{8}$ dowiemy się, że kobieta z Amberley to Wiktoria, królowa Wielkiej Brytanii, do której Nowa Zelandia należała, gdy znaczek stemplowano. Dowiemy się też, że znaczek wydrukowano w Government Printing Office w Wellington na Wyspie Północnej w 1882 r. a zaprojektowano w 1874 r. w firmie Thomas De La Rue \& Co. w Basingstone w Anglii. Uwikłanie znaczka nie dotyczy tylko czasu i miejsca ostemplowania. Są inne miejsca i czasy ważne dla jego istnienia i posiadanych przez niego własności, znaczeń, wartości. Nie byłoby go tutaj, gdyby nie został w 1882 r. wydrukowany w Wellington w firmie mieszczącej się w budynku na rogu Lambton Quay i Bunny Street, którą kierował George Didsbury. Nie byłoby go też, gdyby 8 lat wcześniej nie został zaprojektowany w angielskim mieście w firmie Thomasa De La Rue. Swoją nominalną wartością znaczek uwikłany jest w brytyjski system pieniężny, używany na Wyspach od średniowiecza do 1971 r. Wartość dwóch pensów związana jest z wartością jednego. $Z$ kolei jeden pens to $1 / 12$ szylinga, skoro szyling to 12 pensów.

\footnotetext{
${ }^{8}$ Michel Briefmarken Katalog (Leipzig: Schwaneberger Album, 1936).
} 
Szyling zaś to $1 / 20$ funta, skoro funt to 20 szylingów. Dzisiaj powiemy, że pens to $1 / 240$ funta, skoro funt to 240 pensów ale wtedy mówiono, że funt to 20 tuzinów pensów. Nominalna wartość znaczka jest częścią złożonych relacji średniowiecznego systemu, który po raz pierwszy przedstawiony został przez Karola Wielkiego we Frankfurcie nad Menem w maju 794 r. Ściany budynku, gdzie to się odbyło, nadal można oglądać w centrum miasta w Archäologische Garten, a to oznacza związek tego małego skrawka papieru nie tylko z miejscem i czasem wydrukowania, zaprojektowania, ale i innymi miejscami, czasami, wydarzeniami. To uwikłanie małego papierka w wielość rozmaitych zależności przyczynowych, znaczeniowych, wartościowych z rozmaitymi wydarzeniami, osobami, miejscami, czasami. Gdyby nie panowanie Wiktorii, nie pojawiłaby się ona na znaczku i na świdnickim Rynku, co wiąże go nie tylko z czasami lecz także rozległymi obszarami jej Imperium. Przestrzeń Rynku w dzień naszej Giełdy jest konstytuowana przez obecne na nim przedmioty, a integralną częścią tych przedmiotów są ich związki z innymi miejscami i czasami ważnymi dla ich istnienia, znaczenia, wartości. To oznacza, że przedmioty swoją obecnością także i Rynek wikłają w swoje uwikłania.

Dzięki katalogom i innym źródłom dowiemy się, że znaczek z Århus przedstawia porcelanową wazę i pojemnik na herbatę firmy Royal Copenhagen, ze wzorem, o którym na stronie firmy dowiemy się, że jest pierwszym, najstarszym wprowadzonym w 1775 r., który powstał w rezultacie inspiracji ówczesnych projektantów starym i tradycyjnym wzorem niebieskim porcelany chińskiej. Oczywiście, przedstawione na znaczku wyroby także i kształtem naśladują chińskie wazy i pojemniki na herbatę. Dowiemy się także, że powstanie firmy i uruchomienie produkcji stało się możliwe, gdy inspektor kamieniołomów Niels Birch w 1755 r. odkrył kaolin na bałtyckiej wyspie Bornholm w okolicach Rønne ${ }^{9}$. Kaolin zaś to glina, która jest rezultatem przeobrażenia i zniszczenia twardych skał granodiorytu, które powstały ok. 1,5 mld lat temu a wypiętrzył się na powierzchnię ok. $400 \mathrm{mln}$ lat w okolicach równika tworząc góry, których pozostałością jest Bornholm ${ }^{10}$. Wykonana $\mathrm{z}$ tego kaolinu waza swoim kształtem realizuje wzór Yuhuchunping (玉壶春瓶), czyli kształt gruszki, który pojawił

\footnotetext{
${ }^{9}$ Ludwig Danckert, Leksykon porcelany europejskiej, tłum. Agata Bobkiewicz, Barbara Bukowska, Roman Warszewski (Gdańsk: Literatura Net, 2008), 261.

${ }^{10}$ Jan Bondam, „Kaolinised Granodiorite and its sedimentary cover on Bornholm”, w: Nonmetalic mineral ores, vol. 15 (Utrecht: VNU Science Press, 1984), 319.
} 
się w chińskich świątyniach dynastii Tang (608-917) dla pojemników na świętą wodę $^{11}$. Treść znaczka wikła go z kolejnymi miejscami i czasami, a wraz z nim i przestrzeń relacji naszego Rynku i sam Rynek: wprowadzenie 1. wzoru Royal Copenhagen, odkrycie kaolinu, jego powstawanie w postaci przeobrażeń i sedymentacji granodiorytów, powstanie Bornholmu w okolicach równika około 400 $\mathrm{mln}$ lat temu. Nie będziemy się już zatrzymywać przy drugim naczyniu, pojemniku na herbatę, który też odsyła do kolejnych miejsc i czasów.

Na kolejnym znaczku widzimy szczygła. Ptaki te wraz z ludźmi rozprzestrzeniły się na Euroazję, Afrykę, Australię i Amerykę Południową. Ten przybył z Borsbeek w południowo-wschodniej Antwerpii, gdzie pojawił się na tym znaczku wyemitowanym 11 lutego 1985 r. Nie jest jedynym ptakiem na naszym Rynku. Niedaleko spacerują po bruku mniej kolorowe ale żywe gołębie, zamieszkujące jak szczygły rozległe i odległe od siebie regiony świata. Rynek jest zatem miejscem spotkania także i różnych ptaków.

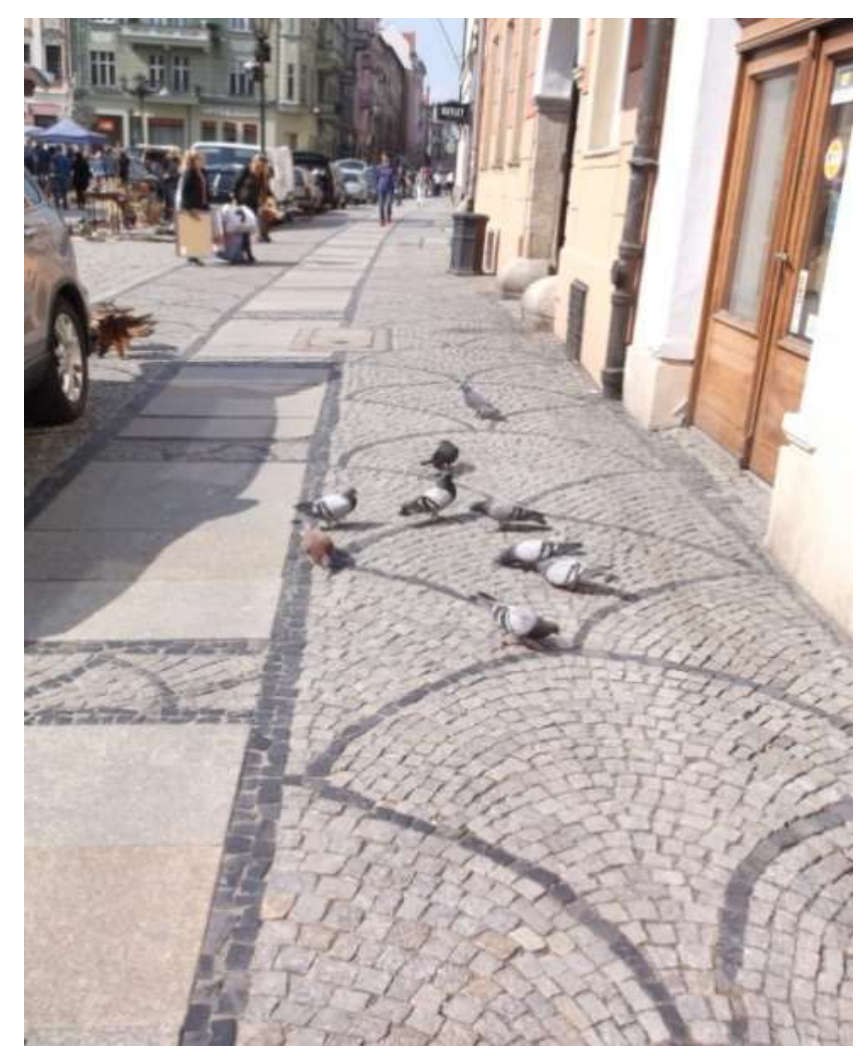

Fot. 8. Gołębie

${ }^{11}$ „A Begginer's Guide to Chinese Porcelain Vase Shapes”, https://oriental-style.weebly.com/blog/a-beginners-guide-to-chinese-porcelain-vase-shapes (dostęp: 06.09.2019). 
Z filatelistycznego katalogu dowiemy się, że znaczek zaprojektował André Buzin, urodzony 31 grudnia 1946 r. w walońskim Dinant w południowowschodniej Belgii. Szczygieł ze znaczka wiąże nasz Rynek z rozległymi obszarami, gdzie żyją przedstawiciele jego gatunku, a także z miejscem i czasem narodzin André Buzina, dzięki któremu ten kolorowy ptak pojawił się na znaczku i w Świdnicy.

Za sprawą znaczka z Port Said na Rynku pojawia się Sfinks i piramida. Ta ostatnia ma wysokość ok. 147 m i podstawę o kształcie kwadratu o boku ok. 140 $\mathrm{m}$. To znaczy, że jest większa niż Rynek, lecz mieści się na nim za sprawą małego znaczka. Została wybudowana w Gizie jako grobowiec faraona Cheopsa ok. 2560 r. p.n.e., a w II w. p.n.e. przez Antypatra z Sydonu na śródziemnomorskim wybrzeżu dzisiejszego Libanu została uznana za jeden z siedmiu cudów świata. Za sprawą pojawienia się tej piramidy na Giełdzie nasze tu i teraz poszerza swoje związki z innymi miejscami i czasami o Gizę z III tys. p.n.e. Co do Sydonu, to czy piramida ta pojawiłaby się na znaczku i Rynku, gdyby Antypater nie zaliczył ją do siedmiu cudów świata? Sam znaczek zaprojektowano w znanej nam już firmie Thomasa De La Rue w angielskim Basingstoke a piramidę i Cheopsa wykonano z wapienia z pobliskiego Gizie kamieniołomu Tora, gdzie powstawał miliony lat w eocenie (56-34 mln lat temu) z martwych skorupek małych istot opadających na dno Oceanu Tetydy, jaki znajdował się wtedy między Afryką a formującą się Europą. Mamy zatem i kamieniołom, i znacznie starszy Ocean, którego pozostałością jest Morze Śródziemne.

Dzięki znaczkowi z Taltal w świdnickim spotkaniu uczestniczy znana osobistość. Przy pomocy katalogu Mitchela dowiedziałem się, że to Krzysztof Kolumb. Gdzie indziej można dowiedzieć się, że w 1451 r. urodził się w Genui, 3 sierpnia 1492 wypłynął z Palos w hiszpańskiej Andaluzji, a 12 grudnia 1492 r. dopłynął do Wysp Bahama. Czy pojawiłby się na znaczku i Giełdzie, gdyby tego nie zrobił? Jeśli nie, to jego obecność oznacza kolejne związki z kolejnymi miejscami i chwilami. Mówiliśmy już o związku z Taltal, miasteczkiem, gdzie został ostemplowany. Miasteczko powstało w 1850 r. wraz z kopalnią miedzi El Cobre położoną $20 \mathrm{~km}$ na północ od miasta. Czy zatem obecność znaczka oznacza 
związek naszego Rynku z tą kopalnią? Już dawno wkroczyliśmy na grząski i niepewny grunt, po którym musimy stąpać ostrożnie, jak w kopalni.

Znaczek z Teynampet został wydrukowany w Security Printing Press w Nashik w stanie Macharasztra w zachodnich Indiach, z okazji inauguracji New Delhi. Na znaczku widzimy Jerzego $\mathrm{V}$ w koronie cesarza Indii, który uczestniczył w położeniu kamienia węgielnego pod budowę miasta oraz Puranę Qila, najstarszy fort Delhi z III wieku p.n.e., choć jego ówczesne i dzisiejsze mury są pozostałością po budowli postawionej za rządów Sher Szaha Suri w XVI w. ${ }^{12}$ Teynampet nie odsyła nas w tak odległą przeszłość. Jest dzielnicą dawnego Madrasu założonego w 1639 r. jako faktoria handlowa przez Brytyjską Kompanię Indii Wschodnich. Nominalna wartość znaczka wikła go i nas w dalszą przeszłość. To 1/16 rupii i została wprowadzona w czasach powstawania Modrasu i rządów Shahajahana (1628-58), jednak jest realizacją systemu rachunkowego, wagowego i pieniężnego znacznie starszego, w którym jednostka dzielona jest na dwie części, każda z nich na dwie i tak dalej. Otrzymujemy ciąg 1, 2, 4, 8, 16, $32 .$. Taki sposób liczenia jest starszy niż indyjskie miasta nad Gangesem. Stosowany był w miastach Doliny Indusu w epoce brązu w III tys. p.n.e., takich jak Harappa, Mohendżo Daro, gdzie archeolodzy odnajdują odważniki tego systemu ${ }^{13}$.

Także z katalogu takiego jak Michel dowiemy się, że znaczek z Tunisu przedstawia meczet Wielkiego Wezyra Yusufa Saheb Ettabaâ z Halfaouine, dzielnicy Tunisu. Został otwarty w 1814 r., a towarzyszy mu minaret zbudowany na planie oktagonu. Tym samym nawiązuje on do minaretu meczetu Paszy Hammouda, otwartego w Tunisie w 1655 r., oraz do minaretu meczetu sułtana Hasana w Kairze z 1362 r., które także zbudowane zostały na planie oktagonalnym. Jednocześnie meczet i minaret z naszego znaczka na inne sposoby nawiązują do wielu innych meczetów i minaretów Islamu z różnych krajów. Obecność

${ }^{12}$ Divya A, „New find in Purana Qila pushes Delhi history back by centuries”, The Indian $E X$ press, 27.01.2018, https://indianexpress.com/article/cities/delhi/new-find-in-purana-qila-pushescity-history-back-by-centuries-5040743/ (dostęp 23.08.2019).

${ }^{13}$ Ahmed Mukhtar, Ancient Pakistan. An Archaeological History, Vol. 3: Harappan Civilization. The Material Culture (Reidsville: Foursome Group, 2014). 
tego meczetu i minaretu na świdnickim Rynku oznacza powiększenie listy jego związków z kolejnymi miejscami i czasami Islamu, jego wydarzeniami, znaczeniami, wartościami.

\section{Nie tylko znaczki}

Nasze znaczki jak i inne przedmioty swoją obecnością wikłają Rynek dzisiejszej Giełdy w niezliczoną ilość własnych powiązań przyczyn i skutków, znaczeń i wartości z równie niezliczoną ilością innych miejsc i czasów mniej lub bardziej odległych. Zgromadzone na Rynku przedmioty stanowią także rozmaite relacje między sobą. Przybysze ze Wschodu rozglądają się po Rynku wśród innych ceramicznych figurek (Fot. 5), Budda odpoczywa wśród Madonn (Fot. 6), a Lenin spotyka się z Krakowiakami (Fot. 9).

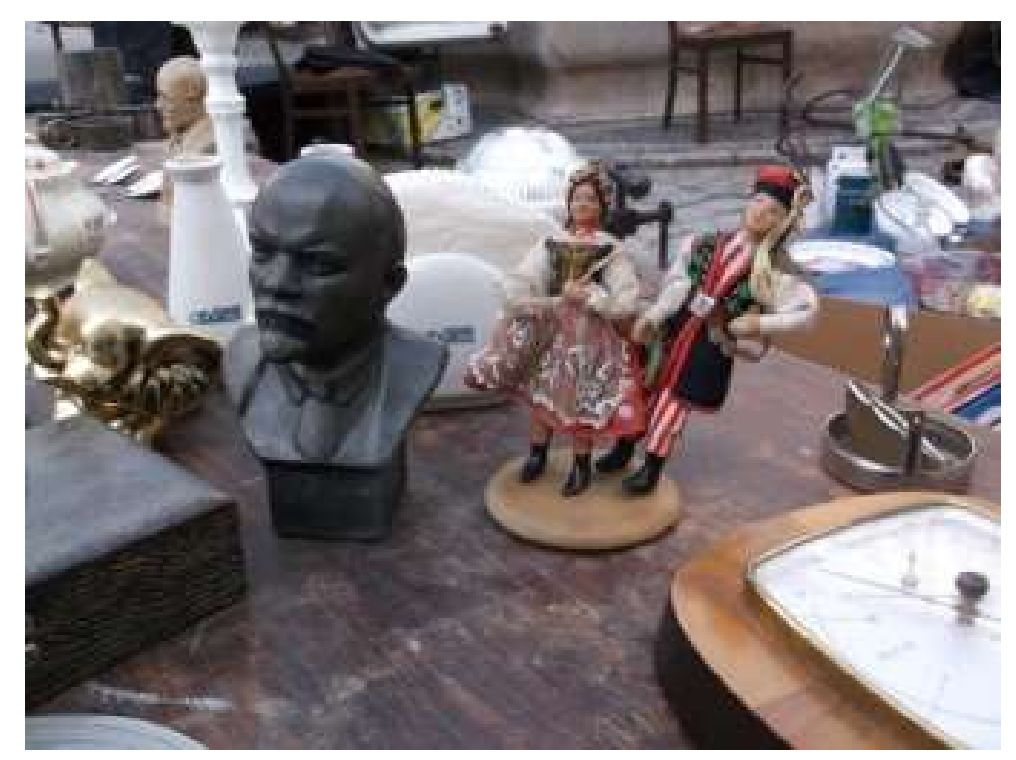

Fot. 9. Lenin i Krakowiacy

To nie tylko spotkania przedmiotów. Skoro są one nadal częścią innych miejsc i czasów to one także się tu spotykają. Z informacji na spodzie Krakowiaków dowiadujemy się, że wykonano ich w Spółdzielni Pracy Rękodzieła Ludowego w Krakowie przy ul. Mrozowej 31a. Na figurce Lenina jest podpis artysty, to Геворг Арутюнович Геворкян. W Internecie odnajdziemy informację, że 
oryginał, którego nasza figurka jest kopią, znajduje się w Muzeum w rosyjskim Murmańsku, a powstał w armeńskim Erewaniu w 1980 r. Spotkanie obu przedmiotów to zatem specyficzne spotkanie Krakowa i Erewania, których - mimo upływu czasu - są częścią a także spotkanie znaczeń i wartości folkloru i komunizmu. Dzięki Buddzie i Madonnom, na naszym Rynku spotykają się dwie wielkie religie Wschodu i Zachodu ze swoimi znaczeniami i wartościami a także czas życia Buddy z czasem życia Maryi, pomimo dzielących je stuleci.

\section{Lokalność jako splot wielu innych lokalności}

Ulokowanie naszych znaczków obok siebie w małym klaserze także oznacza spotkania różnych miejsc i czasów. Obok siebie leżą egipski Port Said, nowozelandzki Amberley, indyjski Teynampet, duński Århus, chilijski Taltal i afrykański Tunis. Mimo, iż są cząstkami odległych od siebie czasów spotkały się tu na świdnickim Rynku w to niedzielne, majowe przedpołudnie. 10 grudnia 1886 r., 10 listopada 1976 r., 21 czerwca 1934 r., 14 marca 1931 r., 19 maja 1987 r. i 4 kwietnia 1901 r. razem. Czy to możliwe? To oznaczałoby brak granic oddzielających określone miejsce od innych. Zamiast granic mamy związki zachodzące pomiędzy różnymi lokalnościami, z których każda uwikłana jest w niepowtarzalny ich splot nadający jej unikalny charakter. Podobnie z czasami i chwilami. Zamiast granic i wyraźnych różnic miedzy tym czasem a innym, tą chwilą a tamtą mamy powiązania. Spotkanie znaczków na świdnickim Rynku oznacza niepowtarzalny i unikalny splot sieci powiązań, w które są uwikłane. Nie chodzi tylko o zależności przestrzenne, czasowe i przyczynowo-skutkowe. To także związki między znaczeniami i wartościami. Wiktoria spotkała się tu z Kolumbem, piramida $z$ meczetem i murami obronnego fortu, siedzący na gałązce ostu szczygieł z roślinnymi ornamentami ceramiki, brytyjski imperializm z hiszpańskim kolonializmem, egipskie wierzenia religijne $z$ islamem a wznoszące się do nieba piramida i minaret $\mathrm{z}$ murami, które chronią przed otoczeniem. To tylko wybrane przykłady z licznej listy wielu relacji, jakie możemy dostrzec na Rynku w czasie Giełdy. Oznacza to ogromną gęstwinę powiązań między spotykającymi się tu przedmiotami, ludźmi, samych Rynkiem, co stanowi złożoną sieć relacji uwikłaną $\mathrm{w}$ dalsze związki $\mathrm{z}$ innymi miejscami i czasami rozciągające się daleko w czas i przestrzeń. Z tego powodu i w tym znaczeniu powiemy, że Rynek jest 
światem, a świat Rynkiem, mimo że nie przestają być sobą. Podobnie teraźniejszość jest przeszłością, a przeszłość teraźniejszością. A co z przyszłością?

Nie oznacza to, że znaleźliśmy się w jakimś wyjątkowym magicznym miejscu. Przeciwnie. Inne miejsca i chwile mają podobny charakter, choć nie zawsze na to zwracamy uwagę. Na Giełdzie Staroci jest to może bardziej wyraźne niż gdzie indziej. Żyjemy w gąszczu powiązań o ogromnej złożoności. Zwracamy uwagę tylko na nieliczne. Nie sądzę, byśmy mogli dostrzec i zrozumieć całość. Ale i tak to, co dostrzegamy i to, czego nie zauważamy, jest środowiskiem naszego życia. Jesteśmy tu dzięki miejscom, z których przybyliśmy a jesteśmy teraz dzięki naszej przeszłości. Znaczenia i wartość ceramiki duńskiej są zrozumiałe dzięki ceramice chińskiej, z której się wywodzą, tak jak znaczenia i wartość nowozelandzkiego pensa związane są z systemami pieniężnymi, rachunkowymi, wagowymi Średniowiecza, Rzymu, Grecji i starożytnego Bliskiego Wschodu. To, że rozpoznajemy tylko nieliczne związki, będące fragmentem świata, w którym żyjemy, nie zmienia jego ogromu złożoności, bez której nie byłoby możliwe istnienia nasze i dostrzeganych przez nas jego części.

\section{Miejsce jako inne miejsca, chwila jako inne chwile - lokalność jako globalność a globalność jako lokalność}

Na obrazie „Żniwiarze” Pietera Breugela Starszego, o którym pisze Tim Ingold $^{14}$ widzimy, jak w cieniu drzewa odpoczywają zmęczeni pracą ludzie w różnym wieku: młodzi i starzy. Wiek zboża i drzewa także się różni, pierwszy trzeba liczyć miesiącami, drugi latami. Widoczny w dali kościół jest zapewne jeszcze starszy. Dalszy brzeg morski to raczej tysiące lat a wzgórza to zapewne miliony. Wszystko jednak tworzy całość przedstawionej przez artystę chwili. Starzy ludzie odpoczywają i posilają się wraz z młodymi. Drzewo rośnie na wzgórzu przysłaniając kościół, a na horyzoncie widać morze. Na naszej Giełdzie jest podobnie. Wśród ludzi są młodzi, starzy i dzieci. Wśród drzew stare i niedawno posadzone młode. Wśród przedmiotów prawie nowe, których historia to kilka miesięcy, tygodni lub dni i stare lub bardzo stare, jak greckie drachmy z czasów Aleksandra Wielkiego czy skamieniały trylobit sprzed ponad $50 \mathrm{mln}$ lat.

${ }^{14}$ Tim Ingold, „The temporality of the landscape”, World Archaeology 25, nr 2 (1993): 152174: DOI: https://doi.org/10.1080/00438243.1993.9980235. 
Wszystko spotyka się na Rynku o średniowiecznym rodowodzie, na którym znajdują się fontanny i rzeźby Posejdona, Atlasa i Ratusz z 1. połowy XVIII w. Sam Rynek pokryty jest kostką wykonaną z granitu, który powstał z powolnego zastygania magmy głęboko pod powierzchnią Ziemi zapewne kilkaset milionów lat temu. Po nim spacerują psy, a nad nim szybują ptaki, które mają własne historie. Wszystko razem tworzy nasze tu i teraz. Świdnicki Rynek nie jest wyjątkiem. Zwróćmy uwagę, że określone miejsce tworzą elementy pochodzące i nadal będące w swoisty sposób składnikami różnych czasów. Zatem określone Tu konstytuowane jest przez różne czasy. A co z teraźniejszością tego miejsca i innych? Przyjmujemy, że teraźniejszość różnych miejsc współistnieje w tej samej chwili. Gdy tu i teraz odbywa się Giełda Staroci, to w tym samym czasie w innych miejscach też się coś dzieje. Jednak gdy uczestniczący w tych wydarzeniach ludzie, psy, ptaki, przedmioty, znaczenia, wartości dotrą na świdnicki Rynek, to już jako składniki jakiejś przeszłości. O ile Tu istnieje dzięki różnym czasom, to Teraz istnieje dzięki różnym miejscom. Tu to różne czasy, a Teraz to różne miejsca. To znaczy, że „tu i teraz” nie jest wyodrębnioną integralną całością. Samo ma nieintegralny charakter, a w swoim istnieniu jest integralną częścią powiązań z innymi czasami i miejscami, dzięki którym istnieje i może być przez nas rozumiane. W tych uwikłaniach lokalność jest globalnością, globalność lokalnością, teraźniejszość przeszłością, a przeszłość teraźniejszością w specyficzne sposoby, które stały się przedmiotem mojego zainteresowania. Dla mnie ich wyjaśnienie i zrozumienie jest nadal zadaniem. To dobrze, bo dzięki temu nasze życie i świat są ciekawe.

\section{Bibliografia}

A Begginer's Guide to Chinese Porcelain Vase Shapes, https://oriental-style.weebly.com/blog/a-beginners-guide-to-chinese-porcelain-vase-shapes (dostęp: 06.09 . 2019).

Bondam, Jan. „Kaolinised Granodiorite and its sedimentary cover on Bornholm”. W: Nonmetalic mineral ores. Vol. 15. Utrecht: VNU Science Press, 1984.

Danckert, Ludwig. Leksykon porcelany europejskiej. Tłum. Agata Bobkiewicz, Barbara Bukowska, Roman Warszewski. Gdańsk: Literatura Net, 2008. 
Divya A. „New find in Purana Qila pushes Delhi history back by centuries”. The Indian EXpress, 27.01.2018, https://indianexpress.com/article/cities/delhi/new-find-in-puranaqila-pushes-city-history-back-by-centuries-5040743/ Dostęp: 23.08.2019.

Gibson-Graham, J.K. „Beyond Global vs. Local: Economic Politics Outside the Binary Frame". W: Geographies of Power: Placing Scale, red. Andrew Herod, Melissa Wright, 25-60. Oxford: Blackwell, 2002.

Ingold, Tim. „The Temporality of the Landscape”. World Archaeology 25, nr 2 (1993): 152-174. DOI: https://doi.org/10.1080/00438243.1993.9980235

Michel Briefmarken Katalog. Leipzig: Schwaneberger Album, 1936.

Mukhtar, Ahmed. Ancient Pakistan. An Archaeological History. Vol. 3: Harappan Civilization. The Material Culture. Reidsville: Foursome Group, 2014.

Olsen, Bjørnar. W obronie rzeczy. Archeologia i ontologia przedmiotów. Tłum. Bożena Shallcross. Warszawa: Instytut Badań Literackich PAN, 2013.

„Port Said Post Office, https://www.ansichtskartenversand.com/ak/93-old-postcard/34029City-Port-Said/8218542-AK-Port-Said-Egyptian-Post-Office/?\&lang=2 Dostęp: 21.08. 2019.

Schulz, Brunon. Sklepy cynamonowe. Sanatorium pod klepsydrą. Kraków: Wydawnictwo Literackie, 1978.

\section{Summary}

\section{Moments, places, people, objects}

The Flea Market at the Market Square of Świdnica is a research area for relationships between objects, places, and times. The items collected here have causal, temporal, spatial, material, semantic, and valuable relationships with other locations and periods. By their presence on the Market they contribute to its sphere of relationships. At the same time, they entangle this space with their own connections with many other places and times close and distant. All this entangles the world with the Market, making them indistinguishable from each other. The present becomes the past; the past is the present. These conclusions concern not only the Świdnica Market Square but also other places and moments, undermining our current perception of these relations.

Keywords: time, place, objects, locality, globality 


\section{Zusammenfassung}

\section{Augenblicke, Orte, Menschen, Gegenstände}

Der Flohmarkt in Świdnica ist das Gebiet der Forschung von Beziehungen, die zwischen den Gegenständen, Orten und Zeiten bestehen. Die hier versammelten Gegenstände sind mit ihren Kausal-, Zeit-, Raum-, Material-, Bedeutungs- und Wertzusammenhängen in Wechselbeziehungen mit anderen Orten und Zeiten verwickelt. Durch ihre Präsenz auf dem Markt gestalten sie seinen Beziehungsraum mit. Sie verstricken gleichzeitig diesen Raum in eigene Beziehungen mit vielen anderen Orten sowie ferneren und näheren Augenblicken. Aufgrund dessen ist der Markt auf eine besondere Art die Welt und die Welt ist der Markt. Die Gegenwart ist Vergangenheit und die Vergangenheit Gegenwart. Diese Schlussfolgerungen beziehen sich nicht allein auf den Markt von Świdnica, sondern auch auf viele andere Orte und Augenblicke, die unsere bisherige Wahrnehmung dieser Beziehungen hinterfragen.

\section{Schlüsselworte: Zeit, Ort, Gegenstände, Lokalität, Globalität}

Information about Author:

ADAM NOBIS, prof. dr hab., Wrocław University; address for correspondence: Institute of Cultural Studies, Global Studies Laboratory, 50-139 Wrocław, ul. Szewska 50, Poland; e-mail: adam.nobis@uwr.edu.pl 